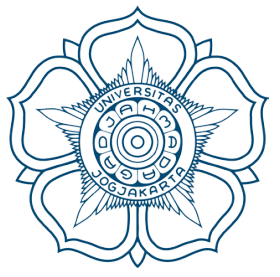

Tittle

: THE LEGAL FORCE OF AN AUDIT BY THE BOARD OF INDONESIA FOR THE PROOF OF CORRUPTIONS (CRITICAL CASE OVER THE PURCHASE OF SUMBER WARAS HOSPITAL)

Author : Yusi Amdani

MIMBAR HUKUM

DOI $\quad:$ http://doi.org/10.22146/jmh.25490

Publisher : Faculty of Law Universitas Gadjah Mada

URL : jurnal.ugm.ac.id/jmh

E Issn : :2443-0994

P Issn : :0852-100x 


\title{
THE LEGAL FORCE OF AN AUDIT BY THE BOARD OF INDONESIA FOR THE PROOF OF CORRUPTIONS (Critical Case over the Purchase of Sumber Waras Hospital)
}

\author{
Yusi Amdani*
}

Criminal Law Department, Faculty of Law University of Samudra

Gd. Baru Fakultas Hukum, Jl. Meurandeh, Langsa Lama, Langsa, Aceh 24416

\begin{abstract}
The audit results of the Audit Board of Indonesia (BPK) stated that the purchase of Sumber Waras Hospital by the Government of DKI Jakarta caused state losses. It's submitted by BPK to the Corruption Eradication Commission (KPK). However, it's not used as the basis of proof since KPK didn't find any state loss. This study examines position and consequences the audit of BPK that not used as basis of investigation, while it's actually possible to be used as evidence in corruption cases. KPK shouldn't ignore it, moreover to test the results that have been in accordance with the standards.
\end{abstract}

Keywords: legal strength, audit of the state audit board, state loss, and corruption.

\section{Intisari}

Hasil audit BPK menerangkan bahwa pembelian Rumah Sakit Sumber Waras oleh Pemprov DKI Jakarta menyebabkan kerugian negara sebesar Rp. 191 miliar. Hasil audit tersebut diserahkan BPK kepada KPK. Namun, tidak dijadikan sebagai dasar pembuktian oleh KPK, dimana dalam proses penyelidikan KPK menilai tidak adanya unsur kerugian negara. Tujuan kajian ini menelaah kedudukan Audit BPK dalam menghitung kerugian negara dan akibat hukum audit Badan Pemeriksa Keuangan yang tidak dijadikan sebagai dasar penyelidikan. Hasil kajian menunjukkan bahwa hasil audit BPK dapat dijadikan sebagai pembuktian perkara korupsi. KPK seharusnya tidak mengabaikan hasil audit BPK apalagi menguji hasil audit yang telah sesuai standar.

Kata kunci: kekuatan hukum, audit badan pemeriksa keuangan, kerugian negara, dan tindak pidana korupsi.

\section{Pokok Muatan}

A. Introduction 560

B. Discussion 562

1. Position of the Audit Held by the Audit Board of Indonesia in Calculating State Losses in the Proof of Corruption

2. Legal Consequence of The Audit by Audit Board of Indonesia Which Is Not Used as the Basis of Investigation in the Case of Sumber Waras

C. Closing 


\section{A. Introduction}

Indonesia is a state of law, as stated in Article 1 paragraph (3) of the 1945 Constitution of the Republic of Indonesia. One of the manifestations of the rule of law is a state based on law and ensures a sense of justice. The sense of justice is reflected in the attitude of the government in maintaining stability and tranquility, that the authority and its actions of state equipment or the government must be lawful or regulated by law. This ensures justice and freedom in the social life of its citizens. ${ }^{1}$

The term of the legal state adopted in Indonesia is a representation of the concept of rechtstaat that is previously mentioned in the Eludication of the 1945 Constitution before the amendment. ${ }^{2}$ The term of rechtstaat comes from continental European system with the basis of enforcement in Indonesia as one of the Dutch colonies. In addition to rechtstaat also known term "the rule of law", which comes from the British state with Anglo-Saxon system. The nature of the legal state between rechtstaat and the rule of law in general is similar, that is every life of the nation governed by law. ${ }^{3}$

The establishment of a legal state, in both continental European and Anglo-Saxon systems, generally consists of 4 (four) elements, namely: (1) the existence of human rights enforcement; (2) the existence of separation and distribution of power; (3) implementation of government based on legislation; and (4) the existence of administrative court in handling disputes. ${ }^{4}$

Yusi Amdani describes that in a state of law, there is a limit of state power against individuals. Human rights protection, especially for criminal suspects is protected in the constitution and laws in force in Indonesia. The 1945 Constitution of the Republic of Indonesia becomes the main basis for citizens to exercise their rights in the life of the nation and state. The constitutional guarantee on human rights is very important for the direction of the implementation of a state administration. ${ }^{5}$

Especially for the executive power in Indonesia, accommodated by the President assisted by the Vice President and a number of State Ministries. In running the government, the performance of the president and its equipment is always supported by a number of budgets passed through the State Budget of Income and Expenditure (APBN). Meanwhile, the provincial and district/municipality levels are accommodated in the Regional Incomen and Expenditure Budget (APBD).

State finance is important as the support of financing the achievement of state goals. The scope of state financial management includes the planning, implementation, supervision, and accountability of state finances. State finances include the State Budget and the Regional Income and Expenditure Budget. Problems encountered include effectiveness and efficiency; priority; leaks and irregularities and low professionalism. Therefore, the principles of state financial management need to be applied in order to be a good governance. ${ }^{6}$

In order for any deficiencies in the government financial statements to be accurately detected as an ingredient in improving the country's financial management and accountability system and as an ingredient in the proper policy-making it is necessary to have an independent, objective, and impartial independent state institution in examining the government's financial statements. The institution is the Audit Board of Indonesia (Badan

\footnotetext{
Abu Daud Busro and Abu Bakar Busro, 1985, Azas-azas Hukum Tata Negara, Ghlmia Indonesia, Jakarta, p. 109.

Satjipto Rahardjo States that some states of law in the world have different backgrounds on its historical and concept. For example in Germany, rechtstaat is a pure legal building unrelated to politics. See also Satjipto Rahardjo, 2009, Negara Hukum yang Membahagiakan Rakyatnya, Genta Publishing, Yogyakarta, p.6.

Moh. Mahfud MD, 2010, Membangun Politik Hukum, Menegakkan Konstitusi, Rajawali Pers, Jakarta, p. 88.

Ibid., p. 90.

Yusi Amdani, "Implikasi Penafsiran Undang-Undang Oleh Hakim Praperadilan Dalam Perkara Tindak Pidana Korupsi”, Mimbar Hukum, Vol. 27, No. 3, October 2015, p. 462.

G.T. Suroso, “Azas-Azas Good Governance dalam Pengelolaan Keuangan Negara”, http://www.bppk.kemenkeu.go.id/publikasi/artikel/147artikel-anggaran-dan-perbendaharaan/20088-azas-azas-good-governance-dalam-pengelolaan-keuangan-negara, accessed on 11 May 2017.
} 
Pemeriksa Keuangan RI, hereinafter BPK).

To realize the objectives of the state, it is necessary to establish a state financial management system based on the principles of order, compliance with laws, efficient, economical, effective, transparent and accountable. Part of the state financial management system is a system of supervision and examination to include whether the state finances have been implemented according to the targets and objectives to be achieved. ${ }^{7}$

The existence of BPK is regulated under Article 23E of the 1945 Constitution of the Republic of Indonesia. In the paragraph (1) it states that, "To check the management and responsibility of the state finance shall be established a free and independent Audit Board." Besides, in the paragraph (2) it is stipulated, "The results of the state financial audit shall be submitted to the People's Legislative Assembly, the Regional Representative Council, and the Regional House of Representatives, in accordance with their authority." In this paragraph describes the duty of the Supreme Audit Board as a state finance auditor that has been used/spent by the budget executive namely the executive power to be submitted to the central and regional legislative institutions according to their authority. The meaning of the authority in question is the authority of the State Audit Board pursuant to Law no. 15 of 2006 on the Audit Board of Indonesia (BPK).

The examination tasks of BPK includes financial audits, performance checks and checks of specific purposes. This audit of state financial management and accountability aims to support law enforcement of state financial irregularities. Although in reality cases of state financial irregularities are still widely encountered resulting in state losses.

Factors other than because of corruption, also caused by the misuse of state finance both by the central government and by local governments. This situation can not be separated from the impact of nepotism in the implementation of government in Indonesia. Lack of openness from both state financial management officials, as well as openness in the use of state finance, is also one of the contributing factors. ${ }^{8}$

Based on Law Number 15 of 2004 on Audit of Management and Responsibility of State Finances, inspection standard is a benchmark for conducting audits of state financial management and responsibility. Inspection standards consist of general standards, implementation standards, and inspection reporting standards mandatory to be guided by BPK and/or auditors. The regulation on financial auditing standards is further stipulated in Regulation of Supreme Audit Board Number 1 of 2017 on Auditing Standards of State. In the second explanation of the Regulation of Audit Board of Indonesia (BPK) Number 1 of 2017 states that, "Implementation of state financial management and accountability audits carried out in order to create a clean government and free from corruption, collusion and nepotism. In order to guarantee the quality of the state financial audit results, the implementation of the examination should be carried out based on an examination standard."

Referring to the provisions of Article 8 paragraph (3) and (4) of Law No. 15 of 2006, it affirms that:

(3) In case the investigation is found to be a criminal element, the BPK shall report the matter to the competent authority in accordance with the provisions of legislation no later than 1 (one) month since the existence of the criminal element is known.

(4) The Report of BPK as referred to in paragraph (3) shall be the basis

Ikhwan Fahrojin and Mokh. Najih, 2008, Menggugat Peran DPR dan BPK dalam Reformasi Keuangan Negara, IB-TRANS Publishing, Malang, p. 12.

Materna Ayu Novita Sekar Arum, 2015, Peran Badan Pemeriksa Keuangan dalam Pemeriksaan terhadap Pengelolaan Keuangan Negara oleh Pemerintah Daerah, (Studi Kasus Pemeriksaan BPK Perwakilan DIY terhadap Pemerintah Kabupaten Sleman), Thesis, Master of Legal Science, Graduate Program of Atma Jaya University, Yogyakarta, p. 6. 
of investigation by an authorized investigator in accordance with the laws and regulations.

One of the cases that occurred based on the audit result of BPK indicated by the criminal element is the case of Sumber Waras Hospital. The case of land purchase of Sumber Sources Hospital was skyrocketed because it allegedly involved the Governor of DKI Jakarta at that time namely Basuki Tjahaja Purnama (Ahok). The audit results of BPK mentioned there are indications of state losses amounting to Rp191 billion. While Ahok stated that the purchase of the land has been in accordance with the procedure and beneficial to the Government of DKI Jakarta. ${ }^{9}$

The Government of DKI Jakarta purchased the land for Sumber Waras Hospital to build a special hospital for cancer, equipped with a number of supporting facilities, including apartments. In an audit conducted by BPK, BPK considered the procedure of land purchase owned by Yayasan Kesehatan Sumber Waras (YKSW) by the Government of DKI Jakarta to violate the regulation. Basically, the State Audit Board considered the Provincial Government to buy Rp800 billion, more expensive than it should be, resulting in a state loss of Rp191 billion. ${ }^{10}$

Due to the existence of indications of corruption in the audit results of the Supreme Audit Board, the results are submitted to the competent authorities in this case, the Corruption Eradication Commission (Komisi Pemberantasan Korupsi, hereinafter KPK). However, in the process of investigation KPK did not see any illegal acts committed by Ahok in relation to the purchase of Sumber Waras Hospital. Thus, the KPK investigation results are in contrast to the audit results of the State
Audit Board of the Jakarta Provincial Government's financial report in 2014.

Based on the above description of the background, then determined some formulation of the problem include: First, how is the position of the audit held by BPK in calculating the state losses in the provision of corruption crime?; Second, what is the legal consequence of the audit held by BPK which is not used as the basis of investigation in the case of Sumber Waras Hospital?

\section{B. Discussion}

1. Position of the Audit Held by the Audit Board of Indonesia in Calculating State Losses in the Proof of Corruption

The criminal act of corruption is believed to be a form of serious threat which consequently not only attacks the joint of the country's economy but also can affect the international economic system and weaken the value of justice. Based on these facts, the eradication and prevention of corruption is not only limited to the responsibility of one State, but requires cooperation between the State both all components within it including the community. ${ }^{11}$

Corruption in Indonesia is difficult to eradicate and continues to grow due to: ${ }^{12}$
a. Inadequate legislation;
b. Weak law enforcement;
c. Permissive attitude to corruption;
d. Lack of exemplary and leadership;
e. The state management system and the management of the business world do not/disregard the principles of good governance; and
f. Various other causes

David Oliver Purba, "Ini Kronologi Pembelian Lahan Sumber Waras oleh Pemprov DKI", http://megapolitan.kompas.com/ read/2016/04/19/05233341/Ini.Kronologi.Pembelian.Lahan.Sumber.Waras.oleh.Pemprov.DKI, accessed on 12 Mei 2017.

10 Editorial Team, "KPK Sebut Tak Ada Pidana di Kasus Ahok- RS Sumber Waras", http://www.bbc.com/indonesia/berita_ indonesia/2016/06/160614 indonesia bpk dpr sumberwaras, accessed on 12 May 2017.

11 Muhammad Fauzan, et al., "Implementasi Pemerintahan Yang Bersih Dalam Kerangka Rencana Aksi Daerah Pemberantasan Korupsi (RADPK)", Dinamika Hukum, Vol. 12, No. 3, September 2012, p. 449.

12 Anonymous, 2006, Pelaksanaan Tata Kelola Pemerintahan yang Baik, Pengalaman Empirik: Kab. Solok, Kota Pekanbaru, Prov. Gorontalo, Kab. Wonosobo, Kota Yogyakarta, Kota Surakarta, Kab. Sragen, Kab. Gianyar, dan Kab. Jembrana, Directorate of Research and Development, Corruption Eradication Commission, Jakarta, p. 1. 
Eradication of conventional criminal corruption has not been effectively able to reduce/ eliminate corruption in the long term. Therefore a comprehensive preventive action effort is required so that efforts of action that directly or indirectly lead to corruption will not occur. Good Governance Practices (good governance) is one of the efforts to prevent corruption that can be done and spearheaded by central and local government. ${ }^{13}$

Political factors that affect the changing role of the organization in this case where public organizations demand the implementation of good governance. The service related to the principles of good governance, as the reform demands are to realize the clean government in the implementation of state supported the basic principles of legal certainty, accountability, transparency, fairness, professionalism, and democratic. ${ }^{14}$

Good Governance as a criterion of good and successful countries in development, even used as a kind of criteria to obtain optimal assistance capability and Good Governance is considered as a standard term for public organizations only in the sense of governance. The coverage of the meaning of Good Governance includes: ${ }^{15}$

a. Values that uphold the willingness/ wishes of the people and values that can improve the ability of the people who in achieving the goals (national) independence, sustainable development and social justice;

b. The functional aspects of effective and efficient governance in the performance of their tasks achieve these goals.

Bintoro Tjokroamidjojo in his paper sees Good Governance as"Aformofdevelopmentmanagement, also called Development Administration, which places the central government's role as Agent of change of a developing society within a developing country." Based on the expert's opinion, it can be concluded that good governance is the process of organizing a solid and responsible, efficient and effective State government by maintaining a constructive interaction between countries, the private sector and society. ${ }^{16}$

Sedarmayanti as quoted by Yenny in his writing concluded that there are four main elements or principles that can give a picture of public administration that characterizes good governance is as follows: ${ }^{17}$

a. Accountability: There is an obligation for the government apparatus to act as the responsible person and accountant for all actions and policies he or she sets.

b. Transparency: Good governance will be transparent to its people, both at the central and regional levels.

c. Openness: To open the opportunity for the people to submit a response and criticism of the government that is judged not transparent.

d. Rule of Law: Good governance has characteristics in the form of guarantee of legal certainty and sense of community justice towards every public policy pursued.

In the implementation of good governance, the KPK, which acts as a trigger mechanism, feels the need to transmit good governance practice successfully in those areas to other areas that have not yet practiced it. Therefore, to obtain detailed information on good governance practices in areas that have been implemented, the Directorate of Research and Development, Prevention Deputy of KPK should have conducted studies in these areas. ${ }^{18}$

The nature and certainty of the law in determining the existence of a government initiative

\footnotetext{
13 Ibid.

4 Yenny, "Prinsip-Prinsip Good Governance, Studi tentang Penerapan Prinsip-Prinsip Good Governance dalam Pelaksanaan Pelayanan Publik di Kantor Camat Samarinda Utara, Kota Samarinda", eJournal Administrasi Negara, Vol. 1, No. 2, (Month) 2013 , p. 197.

18 Anonymous, Pelaksanaan Tata Kelola Pemerintahan yang Baik, Pengalaman Empirik: Kab. Solok, Kota Pekanbaru, Prov. Gorontalo, Kab. Wonosobo, Kota Yogyakarta, Kota Surakarta, Kab. Sragen, Kab. Gianyar, dan Kab. Jembrana, Op. cit., p. 2.
} 
is to ensure in that action the existence of a principle of legal legality. Of course, the implementation there is a result that meaningfully leads to a legal certainty. Thus, the act of freedom of government is highly permissible by law and meets elements of government or ermessen discretion. ${ }^{19}$

Philipus M. Hadjon asserted in his explanation that the discretion in the literature of administrative law of the term often used is free power. In practice there is often a term of policy or wisdom. In comparison the term is used in various administrative legal systems. From the exposure discontent terms should be popularized according to the nature of discretion as unravel as follows: ${ }^{20}$

a. In British administrative law known as discretionary power;

b. In German administrative law known as ermessen (not "freies ermessen") and discretionarie bevoegheden;

c. In Dutch administrative law known as vrij bevoegdheid. Based on the essence of these terms and concepts, in the Draft Law on Administration the term discretion is used.

In addition, the essence of the term discretion is used as opposed to bound authority (gebonden bevoegdheid). The essence is on the choice of government action. The options related to, First, the formula of the norm, for example the use of the phrase "may be", "in certain circumstances", "should be", "properly", and "for the public good". Second, factual conditions, such as disasters and emergencies and so on. ${ }^{21}$

Referring to the level of the concept of good governance and discretion described above, it can be seen the correlation to the case of the construction of Sumber Waras Hospital pioneered by Ahok. Where Ahok issued a policy in buyah land Sumber Waras Health Foundation to serve as Regional
Hospital. DKI Jakarta Provincial Government buys land owned by Sumber Waras Health Foundation worth Rp. 800 billion in the Regional Income and Expenditure Budget (Anggaran Pendapatan Belanja Daerah) of 2014. However, the purchase of this land could cause controversy. The Government of DKI is said to buy at a price more expensive than it should, resulting in state losses amounting to Rp191 billion.

The State Losses in question are analyzed based on the results of an audit conducted by BPK. BPK in exercising its authority shall be guided by state financial auditing standards which shall be guided by conducting audits of state financial management and accountability. Under the provisions of Article 7 of the Regulation of BPK Number 1 of 2017 on State Auditing Standards states that, "Evaluation results on the application and/or results of Nil Tax Assessment Letter (Surat Ketetapan Pajak Nihil/SKPN) development are reported periodically to BPK at least once per year."

Referring to this provision, the Supreme Audit Board is entitled to receive the Nil Tax Assessment Letter (Surat Ketetapan Pajak Nihil/ SKPN) report from every government official in the implementation of state financial management. Financial inspection is an examination that aims to provide reasonable assurance whether the financial statements have been fairly presented, in all material respects, in accordance with generally accepted accounting principles in Indonesia or a comprehensive accounting basis in addition to generally accepted accounting principles in Indonesia. The financial audit conducted by BPK is an examination of the financial reports of the central government and regional governments. This financial audit is conducted by BPK in order to give an opinion statement about the fairness of the information presented in the financial statements of the government. ${ }^{22}$

19 Bega Ragawino, 2006, Hukum Administrasi Negara, Padjadjaran University, Bandung, p. 42.

20 Oheo K. Haris, "Good Governance (Tata Kelola Pemerintahan yang Baik) dalam Pemberian Izin oleh Pemerintah Daerah di Bidang Pertambangan", Yuridika, Vol. 30, No. 1, January - April 2015, p. 38. Ibid.

22 Anonymous, 2008, Petunjuk Pelaksanaan pemeriksaan Keuangan, Keputusan Badan Pemeriksa Keuangan Republik Indonesia Nomor 04/K/I-III.2/5/2008, The Audit Board of Indonesia (Badan Pemeriksa Keuangan RI), Jakarta, p. 3. 
The purpose of a financial audit is to provide reasonable assurance whether the Financial Statement has been fairly presented in all material respects, in accordance with generally accepted accounting principles in Indonesia or a comprehensive accounting basis other than accounting principles generally accepted in Indonesia with due regard to: Conformity of Financial Statements with Accounting Standards; Adequacy of disclosure; Compliance with laws and regulations; Effectiveness of internal control system. $^{23}$

Referring to the standard audit guidelines that must be guided by the Supreme Audit Agency is known that related audit process, the state institutions do not do so arbitrarily. The audit process must be in accordance with BPK regulation on State Auditing Standards. Given the various regulations and standards of the state financial audit, all BPK auditors have strong references and guidance in supporting the implementation of audit work. In addition, the supervision of internal BPK itself to the audit team is also always done, both from the quality aspects of the report and aspects of audit implementation, so that the audit report that is prepared can be accounted professionally. ${ }^{24}$

Related to the audit of the purchase of Rumah Sakit Hospital (RS) Sumber Waras, the audit is a request from the KPK to conduct an investigative audit of the public report on the process of purchasing the hospital. Information from the mass media mentioned the six important findings from the BPK audit results, but from these six findings there is one finding that indicates a regional financial loss that is the financial loss of the region of $\mathrm{Rp}$ $191,334,550,000$ (from the difference between the purchase price between the Provincial Government of DKI and PT CKU) or Rp484,617,100,000 (from difference between purchase price and asset value after purchase due to difference of Tax Object Sale
Value (NJOP)). When purchased from Sumber Waras, the city administration uses Tax Object Sale Value on Kiai Tapa Street at Rp. 20,755,000 per $\mathrm{m}^{2}$, but in fact the location of the land is located on Tomang Utara Street whose Tax Object Sale Value is Rp. 7.44 million per $\mathrm{m}^{2}$. This finding is a polemic and confusion between the DKI government which continues to disput the findings with the BPK which also has a strong basis for the results of audit reports. The audit findings are of course based on a review of the evidence that has undergone a long process in accordance with BPK Audit Standards.

It states that sufficient, competent and relevant evidence must be obtained to be an adequate basis for the findings and recommendations of the examiner. The examiner shall assess the quality and quantity of evidence required to achieve the purpose of the examination. The examiner must therefore perform the evidence test and develop the inspection findings.

But the Sumber Waras audit process is different from the general audit, since it is purely an audit of investigations or audits with a specific purpose that has an appropriate regulatory framework. The investigative audit (as requested by KPK) itself is done considering there has been a strong indication of fraud and violation of legislation. KPK as an institution requesting an investigative audit is also not arbitrary in setting a report to be followed up with an investigative audit. Currently, according to the mechanism, BPK audit results on Sumber Waras are being followed up by the KPK.

Furthermore, the Supreme Audit Board stated in the investigative results of BPK, found there are six irregularities that occurred in the process of purchasing Land Source Sumberas land done by the Provincial Government of DKI Jakarta. As stated by Head of Main Directorate (Planning), Evaluation and Development of State Finance of BPK RI, Bahtiar Arif said there are six irregularities in the 
process of purchasing land. The six irregularities, assessed by BPK resulted in state losses. ${ }^{25}$

Meanwhile, based on BPK Audit Result Report on Local Government Financial Report, there are 6 (six) irregularities in the process of land acquisition of Sumber Waras Hospital such as: ${ }^{26}$

1. Appointment of location of land acquisition of Sumber Waras Hospital worth $\mathrm{Rp} 755,6$ billion by DKI Governor's Implementer (Plt) not according to the provisions. That is Law no. 2 of 2012 on Land Procurement for Development for Public Interest and Presidential Regulation (Perpres) no. 71 of 2012 on the Implementation of Land Procurement for Development in the Public Interest.

2. The disposition of the Governor of DKI Jakarta instructing the Head of Jakarta Development Planning Board (Bappeda) to allocate Rp 755.6 billion for the purchase of Land of Sumber Waras Hospital in APBD 2014 is not in accordance with the provisions.

3. Determination of land location for the construction of Special Heart and Cancer Hospital of DKI Jakarta Provincial Government does not go through a process of feasibility study and reasonable technical studies and indicated to be a formality.

4. The process of land restoration of Sumber Waras Hospital is done when Sumber Waras Health Foundation (YKSW) is still bound by land purchase agreement with other party (PT Ciputra Karya Utama) with lower price. But it was bought by the city government with a higher price of $\mathrm{Rp}$ 191.3 billion.

5. YKSW parties hand over the physical land to the Provincial Government of DKI is not in accordance with the offered by the difference in land price of Rp 484.6 billion

6. Deed of disposal of rights and payments has been made to YKSW worth Rp 755.6 billion before YKSW fulfills its obligation to pay UN arrears RS Sumber Waras valued at Rp 6.6 billion.

Based on the fact above, Miftakhul Huda states that it must be admitted, whether or not the state loss is not an absolute element of corruption. It can be said that the finding of state losses by BPK does not always prove corruption crime. The absence of state losses also can not be concluded there is no crime of corruption. The determinants of whether or not corruption is the fulfillment of elements in the formulation of offense and there is no necessity of real state losses. ${ }^{27}$

As Article 2 paragraph (1) contains the core elements of the offense in that Article, namely, "Any person who unlawfully commits an act of enrichment of himself or another person or a corporation that may harm the state's finances or the economy of the state, is sentenced to imprisonment with life imprisonment or imprisonment for a minimum of 4 (four) years and a maximum of 20 (twenty) years and a fine of at least Rp. 200,000,000.00 (two hundred million rupiah) and at most Rp. 1.000.000.000,00 (one billion rupiah)."

Article 3 states, "Any person who, for the purpose of profiting himself or others or a corporation, misuses the authority, opportunity or means available to him because of the position or position which may harm the state's finances or the economy of the state, is punished by a life imprisonment or imprisonment of at least 1 (one) year and a maximum of 20 (twenty) years and or a fine of at least Rp. 50.000.000,00 (fifty million rupiah) and at most Rp. 1.000.000.000,00 (one billion rupiah)."

For the purposes of the follow-up, so that Article 8 paragraphs (1) and (2) states that, "BPK submits the written examination results to the president, governor, regent/mayor in accordance

\footnotetext{
Lenny Tristia Tambun, "BPK Temukan Enam Penyimpangan Pembelian Lahan RS Sumber Waras", http://www.beritasatu.com/ megapolitan/359927-bpk-temukan-enam-penyimpangan-pembelian-lahan-rs-sumber-waras.html, accessed on 16 May 2017.

26 Ibid.

27 Miftakhul Huda, "Kekuatan dan Implikasi Hukum Hasil Audit BPK terhadap Penyelidikan KPK Kasus Sumber Waras", http://www. miftakhulhuda.com/2016/06/kedudukan-hasil-audit-bpk-dalam.html, accessed on 17 May 2017.
} 
with their authority. The follow up of BPK audit results is notified in writing by the president, governor, and regent/mayor to BPK."

Therefore, in accordance with the authority granted by the law, if in the investigation is found a criminal act of the State Audit Board may report it to the authorized institution. The Report of the Supreme Audit Board is stipulated in Law no. 15 of 2006 shall be the "basis of investigation" authorized in accordance with the laws and regulations.

\section{Legal Consequence of The Audit by Audit Board of Indonesia Which Is Not Used as the Basis of Investigation in the Case of Sumber Waras}

The etymological proof comes from the word "proof" which means something that states the truth of an event. The word "proof" means the process, deeds, and ways of proving. In terminological proof means effort to show the right or wrong of defendant in trial in court. ${ }^{28}$

According to R. Subekti in his quote prove the verification is the attempt to convince the judge of the truth of the proposition or the arguments presented in a dispute. Thus, it appears that the proof is only necessary in a dispute or case before a judge or court. ${ }^{29}$ In line with Subekti, Adami Chazawi interpreted proof as a process of activity to prove something or state about the truth of an event. ${ }^{30}$

Furthermore, according to Eddy O.S. Hiariej in his book mentioned that there are at least six things that need to be reviewed further related to the parameters of proof, each of which is bewistheorie, bewijsmiddelen, bewijsvoering, bewijslaat, bewijskracht, and bewijs minimum. Bewijstheorie is a theory of evidence that is usually used as a basis for judge formation by courts, each of which has four proof theories. Bewijsmiddelen are evidences used to prove the occurrence of a legal event. Bewijsvoering is a test of how to deliver evidence to judges in court. Then, bewijskracht is the strength of the proof of each of the evidences in the series of evidences of a proposition expressed. The last, the bewijs minimum is the minimum proof required in proof to bind judge's freedom. ${ }^{31}$

In the opinion of such experts related to the theory of proof then based on applicable regulation of BPK audit in case of land purchasing of Sumber Waras Hospital can be used as the basis of proof in criminal case. As mentioned in Article 13 of Law No. 15 of 2004 states, "The Examiner may conduct investigative investigations to disclose any indication of loss of state/region and/or criminal element."

In case the Audit Report of BPK is reported to thethe House of Represenative of the Republic of Indonesia (Dewan Perwakilan Rakyat, hereinafter DPR), Regional Representative Council (Dewan Perwakilan Daerah, hereinafter DPD), Regional People's Representative Assembly (Dewan Perwakilan Rakyat Daerah, hereinafter DPRD), and then informed to the President, Governor, Regent and Mayor, then the House requests to KPK to follow up the Sumber Waras case, KPK as the actor of the law enforcement must implement it according to standard of investigation, investigation and prosecution. The same thing when people report to the KPK on the basis of BPK findings. With this condition KPK must respond to case as reports and complaints that can not be ignored.

Moreover, Law No. 15 of 2006 authorizes BPK to monitor the implementation of the follow-up of inspections conducted by the central and regional government agencies whose results are notified in writing to DPR, DPD, DPRD, and the Government. This means that the state losses as BPK findings can not simply be ignored by the Government of DKI Jakarta.

Based on the request of Audit Report of BPK and DPR to follow up the alleged corruption or not criminal, KPK can conduct investigation by 
coordinating with BPK in order to prove corruption crime. Based on the findings of state losses in violation of laws and regulations, the KPK may examine witnesses and experts and others. To deepen the facts, legal basis, and value of loss, the KPK may request BPK to conduct an investigative audit. Audit results with a specific purpose may strengthen previous audits or even results differ. KPK can also prove itself beyond the findings of BPK by inviting experts or request material from the inspectorate general or body that has a function that in order to prove the truth material. ${ }^{32}$

In the process of investigation can not avoid, the Commission makes light about the facts about the elements of the formulation of the offense investigated namely Article 2 paragraph (1) and Article 3 of the Law of Eradication of the Criminal Act of Corruption. With these two chapters as a starting point, KPK should have focused on the elements in the formulation of the two offenses as a formal offense.

In the case of Sumber Waras, the difference mainly lies in the disagreements related to the stages of land procurement, whether the purchase of Land Resources by the Provincial Government of DKI Jakarta using Presidential Regulation No. 71 of 2012 on Implementation of Land Procurement for Development for Public Interest or Presidential Regulation No. 40 of 2014 on Amendment of Presidential Regulation No. 71 of 2012 on Implementation of Land Procurement for Development in the Public Interest.

Regarding the procurement of small-scale land not only implemented in Jakarta, but also implemented in various regions. So the case of Jakarta can be compared with the application of these provisions in the same time frame. In some cases corruption concerning the application of the article has also been handed down by the
Corruption Court. It should be made clear that the existence of Presidential Regulation No. 40 of 2014 is not replacing Presidential Regulation No. 71 of 2012, but only amend Article 120 and Article 121. While Article 121 of Presidential Regulation No. 40 of 2014 only states that, "In the framework of efficiency and effectiveness, land acquisition for Public Interest which is not more than 5 (five) hectares, can be done directly by the Agencies that require land with the right holders of land, by way of buying and selling or exchange exchange or other means agreed upon by both parties." This Article only modifies small-scale procurement of less than 1 (one) hectare size to less than 5 (five) hectares.

So the provisions of Presidential Regulation No. 71 of 2012 is still binding unless otherwise regulated in Presidential Regulation No. 40 of 2014 namely:

a. land acquisition between the related agency which is requiring land and the right holders of land; and

b. by way of buying and selling or exchanging or other means agreed by both parties.

That is, the procurement of land less than 5 hectares is done directly by the agencies that require land in this case is the Provincial Government of DKI Jakarta, with the holders of land rights (Sumber Waras) without going through "Executing Land Procurement" chaired by National Land Agency (Badan Pertanahan Nasional, hereinafter BPN) Regional Head.

The provisions governing the principles of land procurement and planning and preparation stages organized by agencies that require land remain valid. For example, land acquisition of less than 5 (five) hectares is still needed for land acquisition planning documents established by agency heads that include socioeconomic surveys,

32 As the opinion of a criminal law expert, Muzakkir, a lecturer at the Faculty Law Islamic University of Indonesia, stated that: "Proof of corruption especially the elements' can harm the state's finances" based on investigative audit as a "pro justicia" act mandated by Laws must be clear." See "Criminal Expert, Invalid Investigative Audit without Permission of the Audit Board of Indonesia (BPK), Investigative Audit must be conducted under a licensed auditor. Editorial Team, "Izin Penangkapan Dijadikan Perbandingan", http://www.hukumonline.com/ berita/baca/lt544dfb2fdfbca/kata-ahli-pidana--audit-investigatif-tanpa-izin-bpk-tak-sah, accessed on 18 May 2017. 
site feasibility, cost and benefit development analyzes for regions and communities, approximate land values, environmental impacts and possible social impacts resulting from land acquisition and development and others.

In the procurement of land of less than 5 (five) hectares still requires forming a Preparatory Team in charge:
a. carry out the notification of the development plans;
b. carry out initial data collection of development plans location;
c. carry out the Public Consultation of the development plans;
d. preparing the Development Site Location;
e. announce the Determination of Development Sites for the Public Interest; and
f. carry out other tasks related to the Land Acquissition preparation for development of the public interests.

The assessment of the KPK on the basis of the procurement of small-scale land is not fulfilled or is not an element of "unlawful acts" and "abuse of power". The Commission determines the existence of "unlawful acts in the formal sense" in the meaning of criminal law and assesses the "abuse of power" of the jurisprudence of the Supreme Court such as the legal concept that is: to use its authority for any other purpose of the purpose given by the authority. ${ }^{33}$ As known in tracing the elements of this "unlawful act" and "abuse of power", KPK can only use its unlawful nature in a formal and positive sense, not the other way around in a material and negative sense.

In the case of Sumber Waras, is it justified that the Provincial Government of DKI Jakarta in the procurement of land less than 5 (five) hectares then ignore the principles of land acquisition in general and ignore the stages of preparation and planning and consider it just like the process of purchasing land as the general public do. So the interesting question arises in examining the case related to good and clean governance that can the Government of DKI Jakarta based on government discretion (freies ermessen)?

Regarding this answer please judge for yourself based on legal facts. From the process of serious investigation by law enforcers to reveal all the legal facts will be seen whether there are intentional violations of laws and other regulations whether to enrich themselves or others and to benefit themselves or others. Suppose that there is a violation of the law in accordance with the legal facts to be able to declare it as a justified discretion or not in the administrative law needs more in-depth discussion. ${ }^{34}$

If it's proven that elements of the act of unlawfulness in the formal sense include other core elements in the formulation of offense, it is inevitable to finally deal with the inseparable element of "state loss". Similarly, if there is evidence of the use of authority for any other purpose of the intent of such authority.

Based on the principle of administrative law, the Audit Report of BPK is a product of state institution in carrying out its constitutional duties and authority which must be considered true until it can be proven otherwise (presumptio juatae causa/ vermoeden van rechtmatigheid). ${ }^{35}$ So as to prove the untruth of the audit results should be through the process of verification and trial in court. In fact, the results of the audit of BPK which is according to the jurisprudence of the Supreme Court can not be challenged by civil law in the district court.

From the side of criminal law (procedural law), LHP or audit investigation result is "documentary evidence" as legal evidence as according to Criminal Law Procedure Code (Kitab Undang-Undang Hukum Acara Pidana, hereinafter KUHAP). The proof of the letter to prove the

\footnotetext{
See Supreme Court Verdict No. 1340 K/Pid/1992, 17 February 1992.

34 Editorial Team, "Potensi Kriminalisasi, Kata "Dapat” dalam UU Tipikor Inkonstitutional”, Konstitusi, Edition 120, February 2017, p. 15.

35 N.E. Algra, et al., 1983, Kamus Istilah Hukum Fockema Andreae Belanda-Indonesia (First Edition), Binacipta, Jakarta, p. 33. See also Zaki Ulya, 2014, Hukum Acara Peradilan Tata Usaha Negara, (Teaching Materials), Faculty of Law Samudra University, Langsa, p. 10.
} 
existence of state losses, while the findings of violation of law and negligence (crime) as well as the facts more complete is according to the disclosure of legal facts according to the authority of the investigator can still be tested again in the evidentiary process in the hearing. ${ }^{36}$

By the verdict of the Constitutional Court examining the provisions of expert information, it is understood that the expert's information must be interpreted as the Constitutional Court's verdict, namely the expert's statement, not the BPK examiner's testimony which makes the crime finding. ${ }^{37}$ A BPK examiner who finds a criminal offense only provides information in an examination that should only be placed as a witness, a witness who knows the process of Audit Report discovery and manufacture. So without the testimony of BPK examiner who found also not a problem, because the audit results are enough. For the sake of deepening, in the process of investigation and investigation, KPK can complete the audit result with auditor testimony examining and other evidence related to state losses.

It is precisely interesting if in certain cases, the Commission requested an audit of BPK investigations then suppose the Commission also requested to BPKP to re-audit and the results are different. In this case, for instance, it cannot be separated from the standard of their examination. Suppose the BPKP audit results always say the audit is done based on the documents received.

Although the results of the BPK audit should be considered correct and as a valid evidence, the presence or absence of corruption offenses depends on the investigator's assessment of the other elements. If other elements are proven then the loss of the country uses the results of the audit that has been done. If there are basic differences resulting in differences in the value of the loss, the KPK may request a re-audit. Otherwise, if other elements are not proven, automatic state losses have no meaning in the criminal process because it is not a crime of corruption.

As aforementioned, KPK should not test the quality of the audit results that are in accordance with their standard of examination, moreover the audit conducted in performing the duties and authority of the constitution and not by the private/ independent auditor, can not be aborted with the information of the expert/witness who is not doing a thorough check up to the physical check in the field. In this case the Commission has been a judge in the investigation. Therefore, the Chairman of KPK statement regarding the absence of state losses based on the invited expert's statement is a one-sided assessment. This should be proven in court. As long as the expert proves other elements in the investigation process is still acceptable, but from the expert's explanation that annulled the state losses in the Audit Report of BPK, and the results of the investigative audit.

As mentioned in Article 20 paragraph (1) of Law no. 15 of 2006 on the Audit Board of Indonesia, namely: "Officials shall follow up on recommendations in inspection report". Furthermore Article 20 paragraph (5) of Law No. 15 of 2004 on Audit of State Financial Management and Accountability also states: "Officials known to not perform the obligations referred to in paragraph (1) may be subject to administrative sanctions in accordance with the provisions of legislation in the field of personnel." Such matter is expressly stated also in Article 35 paragraph (1) of Law No. 17 of 2003 on State Finances which states, "Any state official and civil servant not a treasurer in violation of the law or neglect his obligation either directly or indirectly which is detrimental to state finance is obliged to compensate for such loss."

On the basis of the three laws, it requires officials to follow up on the BPK audit results. If it is not followed up it carries legal implications of imposing administrative sanctions on the official.

\footnotetext{
36 See Art. 184 Criminal Law Procedural Code (KUHAP). See also M. Yahya Harahap, 2012, Pembahasan Permasalahan dan Penerapan KUHAP Pemeriksaan Sidang Pengadilan, Banding, Kasasi, dan Peninjauan Kembali, Sinar Grafika, Jakarta, p. 71

37 See Consideration Part of the Constitutional Court Verdict No. 54/PUU-XII/2014.
} 
In the case of Sumber Waras, so that if the followup is not implemented then it is true what stated by Governor Ahok that the sanctions are administrative sanctions. However, it is noteworthy that, the law also authorizes the reporting of criminal offenses and BPK findings that are positioned as the "basis of investigation".

None of this would have happened if the provisions of the law stipulated an objection mechanism against the BPK audit results and there were also mechanisms to test the KPK's decision when not raising the investigation status to the investigation. That is, the two institutions are very open the existence of irregularities. So far, the news has strongly cornered BPK with KPK's statement that there is no state loss that has been almost never done by law enforcement, because this is always done by legal advisors of corruption suspects.

\section{Conclusion}

The position of the Audit Board of the Republic of Indonesia (BPK) as the basis for corruption proof of Sumber Waras Hospital has been ostracized by Corruption Eradication Commission (KPK). The long process of audit results of the BPK finally stated that there is state losses over the case of Sumber Waras Hospital. As to its authority, the results of the audit are submitted to regional and central legislative bodies for follow up. Meanwhile, if the indication of criminal acts of corruption, especially in the case of the occurrence of state losses then the audit can be submitted to law enforcement officers in this case the KPK, to serve as the basis for proof. KPK statement which concludes that there is no element of state loss in the case of Sumber Waras Hospital is done by heeding from audit result of BPK.

Based on Law No. 15 of 2006, the audit results should be the "basis of investigation" for the authorities in accordance with the laws and regulations. Where KPK should be able to conduct an investigation by coordinating with Bada Pemeriksa Keuangan in order to prove the criminal act of corruption. Based on the theory of criminal proof that should be investigated process and investigation KPK can not ignore the results of BPK audit, especially if the results of investigative audits at the request of the KPK. Therefore, in case of Investigation of Sumber Waras case, KPK should not test the quality of audit result which is in accordance with inspection standard.

\section{REFERENCES}

A. Book

Algra, N.E., et al., 1983, Kamus Istilah Hukum Fockema Andreae Belanda-Indonesia (First Edition), Binacipta, Jakarta.

Anonymous, 2006, Pelaksanaan Tata Kelola Pemerintahan Yang Baik, Pengalaman Empirik: Kab. Solok, Kota Pekanbaru, Prov. Gorontalo, Kab. Wonosobo, Kota Yogyakarta, Kota Surakarta, Kab. Sragen, Kab. Gianyar, dan Kab. Jembrana, Directorate of Research and Development, Corruption Eradication Commission, Jakarta.

Anonymous, 2008, Modul Penerapan Tata Kepemerintahan Yang Baik (Good Public Governance) di Indonesia, Bappenas,
Jakarta.

Anonymous, 2008, Petunjuk Pelaksanaan pemeriksaan Keuangan, Keputusan Badan Pemeriksa Keuangan Republik Indonesia Nomor 04/K/I-III.2/5/2008, The Audit Board of Indonesia (Badan Pemeriksa Keuangan RI), Jakarta.

Chazawi, Adami, 2003 Hukurn Pidana Materiil dan Formil Korupsi di Indonesia, Bayumedia Pulishing, Malang.

Daud Busro, Abu dan Abu Bakar Busro, 1985, Azas-azas Hukum Tata Negara, Ghalia Indonesia, Jakarta

Departemen Pendidikan dan Kebudayaan, 1995, Kamus Bahasa Indonesia, Balai Pustaka, 
Jakarta.

Fahrojin, Ikhwan and Mokh. Najih, 2008, Menggugat Peran DPR dan BPK dalam Reformasi Keuangan Negara, IB-TRANS Publishing, Malang.

Harahap, M. Yahya, 2012, Pembahasan Permasalahan dan Penerapan KUHAP Pemeriksaan Sidang Pengadilan, Banding, Kasasi, dan Peninjauan Kembali, Sinar Grafika, Jakarta.

Hiariej, Eddy O.S., 2012, Teori dan Hukum Pembuktian, Erlangga, Jakarta.

Materna, Ayu Novita Sekar Arum, 2015, Peran Badan Pemeriksa Keuangan Dalam Pemeriksaan Terhadap Pengelolaan Keuangan Negara Oleh Pemerintah Daerah, (Studi kasus Pemeriksaan BPK Perwakilan DIY terhadap Pemerintah Kabupaten Sleman), Thesis, Master of Legal Science, Graduate Programe of Atma Jaya University, Yogyakarta.

MD., Moh. Mahfud, 2010, Membangun Politik Hukum, Menegakkan Konstitusi, Rajawali Pers, Jakarta.

Ragawino, Bega, 2006, Hukum Administrasi Negara, Universitas Padjadjaran Bandung.

Rahardjo, Satjipto, 2009, Negara Hukum yang Membahagiakan Rakyatnya, Genta Publishing, Yogyakarta.

Subekti, R., 1983, Hukum Pembuktian, Pradnya Paramita, Jakarta.

Ulya, Zaki, 2014, Hukum Acara Peradilan Tata Usaha Negara (Teaching Materials), Faculty of Law Samudra University, Langsa.

\section{B. Journal Articles}

Amdani, Yusi, "Implikasi Penafsiran UndangUndang oleh Hakim Praperadilan dalam Perkara Tindak Pidana Korupsi”, Mimbar Hukum, Vol. 27, No. 3, October 2015.

Fauzan, Muhammad, et al., "Implementasi Pemerintahan yang Bersih dalam Kerangka Rencana Aksi Daerah Pemberantasan Korupsi (RAD-PK)", Dinamika Hukum, Vol.
12 No. 3, September 2012.

Haris, Oheo K., "Good Governance (Tata Kelola Pemerintahan yang Baik) dalam Pemberian Izin oleh Pemerintah Daerah di Bidang Pertambangan", Yuridika, Vol. 30, No. 1, January - April 2015.

Yenny, "Prinsip-Prinsip Good Governance, Studi tentang Penerapan Prinsip-Prinsip Good Governance dalam Pelaksanaan Pelayanan Publik di Kantor Camat Samarinda Utara, Kota Samarinda", eJournal Administrasi Negara, Vol. 1, No. 2, 2013.

\section{Internet Articles}

Ansori, Mufid, "Temuan BPK terkait pembelian RS Sumber Waras", http://www.antaranews. com/berita/566299/temuan-bpk-terkaitpembelian-rs-sumber-waras, accessed on 16 May 2017.

Editorial Team, "Kata Ahli Pidana, Audit Investigatif Tanpa Izin BPK Tak Sah, Audit Investigatif Harus Dilakukan Auditor Yang Memiliki Lisensi Khusus. Izin Penangkapan Dijadikan Perbandingan", http://www.hukumonline. com/berita/baca/lt544dfb2fdfbca/kata-ahlipidana--audit-investigatif-tanpa-izin-bpktak-sah, accessed on 18 May 2017.

Editorial Team, "KPK Sebut Tak Ada Pidana di Kasus Ahok- RS Sumber Waras", http://www.bbc.com/indonesia/berita_ indonesia/2016/06/160614_indonesia_bpk_ dpr_sumberwaras, accessed on 12 May 2017.

G.T., Suroso, "Azas-Azas Good Governance dalam Pengelolaan Keuangan Negara", http://www.bppk.kemenkeu.go.id/publikasi/ artikel/147-artikel-anggaran-danperbendaharaan/20088-azas-azas-goodgovernance-dalam-pengelolaan-keuangannegara, accessed on 11 Mei 2017.

Huda, Miftakhul, "Kekuatan dan Implikasi Hukum Hasil Audit BPK terhadap Penyelidikan KPK Kasus Sumber Waras", http://www. miftakhulhuda.com/2016/06/kedudukanhasil-audit-bpk-dalam.html, accessed on 17 
May 2017.

Purba, David Oliver, "Ini Kronologi Pembelian Lahan Sumber Waras oleh Pemprov DKI, http://megapolitan.kompas.com/ read/2016/04/19/05233341/Ini.Kronologi. Pembelian.Lahan.Sumber.Waras.oleh. Pemprov.DKI, accessed on 12 May 2017.

Tambun, Lenny Tristia, "BPK Temukan Enam Penyimpangan Pembelian Lahan RS
Sumber Waras", http://www.beritasatu.com/ megapolitan/359927-bpk-temukan-enampenyimpangan-pembelian-lahan-rs-sumberwaras.html, accessed on 16 May 2017. 